Note

\section{Occurrence of Free Ceramide in Acetobacter xylinum}

\author{
Yasutaka TAHARA, Akira NaKagawa \\ and Yuzo Yamada
}

Laboratory of Applied Microbiology, Department of Agricultural Chemistry, Shizuoka University, Shizuoka 422, Japan

Received June 23, 1986

We have studied the membrane lipids of acetic acid bacteria, which are capable of growing in an acidic medium near $\mathrm{pH} 3.0$, in an attempt to elucidate the relationship between the lipid composition and the tolerance to acidic $\mathrm{pH}$. So far, as being characteristic of the lipids of the organisms, we have reported an ornithine lipid, ${ }^{1,2)}$ a tauro-ornithine lipid ${ }^{3,4)}$ and a phosphatidylcholine $^{5)}$ together with other identified phospholipids. ${ }^{6)}$ In a further investigation, we found the occurrence of a free ceramide in the alkali-stable lipids of Acetobacter xylinum. This paper describes the isolation and molecular species of the ceramide.

Acetobacter xylinum IFO 3288 was grown with shaking in a medium containing $1.5 \%$ glycerol, $0.5 \%$ glucose, $0.5 \%$ yeast extract, $0.5 \%$ peptone and $0.1 \%$ malt extract, $\mathrm{pH} 6.8$, at $30^{\circ} \mathrm{C}$ for $24 \mathrm{hr}$. Cells were harvested and the lipids were extracted by the method of Bligh and Dyer. ${ }^{7)}$ The extractable lipids were hydrolyzed with $0.5 \mathrm{~N} \mathrm{KOH}$ in methanol for $4 \mathrm{hr}$ at $30^{\circ} \mathrm{C}$ to yield alkali-stable lipids, which were developed on a silica gel $\mathrm{G}$ thin-layer plate with a solvent system of $\mathrm{CHCl}_{3}-\mathrm{CH}_{3} \mathrm{OH}-\mathrm{CH}_{3} \mathrm{COOH}(90: 10: 2, \mathrm{v} / \mathrm{v})$.

The thin-layer chromatogram is shown in Fig. 1A. Spot $\mathrm{d}$ did not react with either ninhydrin or ammonium molybdenum, and the $R f$ value coincided with that of the ceramide standard, $\mathrm{N}$-stearoyl-dihydrosphingosine (Sigma, St. Louis). This lipid also occurred at the same position on the chromatogram of the original lipids (Fig. 1B). The infrared spectrum of the lipid showed the presence of a hydrocarbon chain $\left(2930\right.$ and $\left.2850 \mathrm{~cm}^{-1}\right)$, an amide group (1640 and $\left.1550 \mathrm{~cm}^{-1}\right)$, a hydroxyl group $\left(3400 \sim 3500 \mathrm{~cm}^{-1}\right)$, but no absorption band due to an ester group $\left(1725 \mathrm{~cm}^{-1}\right)$. Acid hydrolysis of the lipid with $2 \mathrm{~N} \mathrm{HCl}$ in methanol at $100^{\circ} \mathrm{C}$ for $4 \mathrm{hr}$ gave two compounds, a methyl ester of fatty acid and a long-chain base. The methyl compound was extracted with hexane from the hydrolysate, while the long-chain base was done with ethyl ester from the residual aqueous phase of which $\mathrm{pH}$ had been adjusted at 12 with concentrated $\mathrm{KOH}$.

The occurrence of a long-chain base was first confirmed as a ninhydrin-positive compound, of which the $R f$ value coincided with that of the dihydrosphingosine standard (Sigma, St. Louis) on a silica gel $\mathrm{G}$ thin-layer plate with a solvent system of $\mathrm{CHCl}_{3}-\mathrm{CH}_{3} \mathrm{OH}-\mathrm{CH}_{3} \mathrm{COOH}-\mathrm{H}_{2} \mathrm{O}$ $(100: 20: 12: 5, \mathrm{v} / \mathrm{v})$. Then the long-chain base isolated was trimethylsilylated, and analyzed by gas chromatographymass spectrometry. The gas chromatogram of the trimethylsilyl $\left(\mathrm{Me}_{3} \mathrm{Si}\right)$ derivative with $5 \%$ Silicone SE-30 on Chromosorb W AW-DMCS at $210^{\circ} \mathrm{C}$ gave a single peak, and the retention time coincided with that of the $\mathrm{Me}_{3} \mathrm{Si}$ derivative of the dihydrosphingosine standard. In the mass spectrum, prominent peaks were found at $m / z \mathbf{M}-103$ and $m / z \quad M-132$, due to the $C_{1}-C_{2}$ and $C_{2}-C_{3}$ bond cleavages of the $\mathrm{Me}_{3} \mathrm{Si}$ ester of dihydrosphingosine, and the molecular ion was at $m / z 445 .{ }^{12}$ )

To elucidate whether the hydrocarbon chain is linear or branched, the long-chain base was subjected to periodateoxidation, followed by reduction with $\mathrm{NaBH}_{4}$. The fatty alcohol generated was trimethylsilylated and analyzed by gas chromatography with $5 \%$ Silicone SE- 30 at $180^{\circ} \mathrm{C}$. The chromatogram of the $\mathrm{Me}_{3} \mathrm{Si}$-derivative showed a

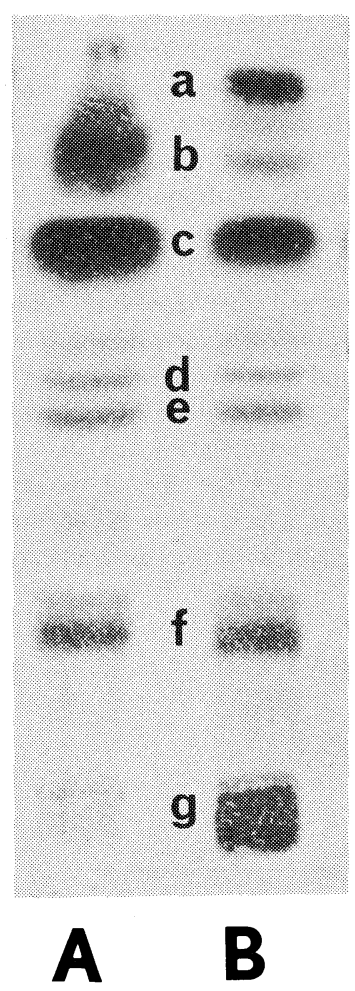

Fig. 1. Thin-layer Chromatograms of Alkali-stable (A) and Original (B) Lipids from Acetobacter xylinum.

The plate was developed with $\mathrm{CHCl}_{3}-\mathrm{CH}_{3} \mathrm{OH}-$ $\mathrm{CH}_{3} \mathrm{COOH}(90: 10: 2, \mathrm{v} / \mathrm{v})$ and the spots were visualized by charring after spraying with $50 \% \mathrm{H}_{2} \mathrm{SO}_{4}$. a and c; fatty acids; b, possibly hopanol ${ }^{8,99}$; , lipid described in the text; e, unknown; f, possibly tetrahydroxybacteriohopanes; ${ }^{8,9}$ $\mathrm{g}$, phospholipids and aminolipids. 
single peak corresponding to that of $\mathrm{Me}_{3} \mathrm{Si}$ ester of the hexadecanol standard, indicating that the long-chain base is a dihydrosphingosine with a straight hydrocarbon chain.

On the other hand, the fatty acid methyl ester was analyzed by gas chromatography with $5 \%$ DEGS on Chromosorb W AW-DMCS at $180^{\circ} \mathrm{C}$. The main peaks on the chromatogram were in agreement with those of authentic myristate, palmitate, stearate and vaccenate, and the amounts of these acids shared 26, 35, 11 and $28 \%$, respectively. No hydroxy fatty acid was detected on the chromatogram.

From the above results, it is obvious that the molecular species of the ceramide is $N$-acyl-dihydrosphingosine, of which the $N$-acyl moiety consists of nonpolar fatty acid described above.

Free ceramide, which is composed of a long-chain base and a fatty acid, is regarded as an essential intermediate in the biosynthesis of sphingolipids. Although sphingolipids are widely distributed in membrane lipids of animals and higher plants, $\left.{ }^{10}\right)$ bacterial sphingolipids, including free ceramides, are extremely limited. To date, they have been reported to occur in some anaerobic rumen bacteria, such as Bacteroides melaninogenicus, ${ }^{11)}$ B. fragilis, ${ }^{12)} \mathrm{B}$. ruminicola ${ }^{13)}$ and $B$. thetaiotaomicron, ${ }^{14)}$ and in aerobic bacteria of Bdellovibrio bacteriovus ${ }^{15)}$ and Xanthomonas campestris. ${ }^{16)}$ These bacterial sphingolipids are involved in both sphingophospholipids and free ceramides, of which the long-chain bases are mainly composed of iso or anteiso branched chains and the $N$-acyl fatty acids are almost all of the hydroxy and/or branched type. The occurrence of sphingoglycolipid has only been found in Flavobacterium devorans. ${ }^{17)}$ The free ceramide from Acetobacter xylinum described here was shown to be $N$-acyl-dihydrosphingosine of which the $N$-acyl moiety is only nonpolar fatty acid, which seems to be quite different in molecular species from other bacterial ceramides.

\section{REFERENCES}

1) Y. Tahara, M. Kameda, Y. Yamada and K. Kondo, Biochim. Biophys. Acta, 450, 225 (1976).

2) Y. Tahara, K. Shinmoto, Y. Yamada and K. Kondo, Agric. Biol. Chem., 42, 1447 (1978).

3) Y. Tahara, M. Kameda, Y. Yamada and K. Kondo, Agric. Biol. Chem., 40, 243 (1976).

4) Y. Tahara, K. Shinmoto, Y. Yamada and K. Kondo, Agric. Biol. Chem., 42, 205 (1978).

5) Y. Tahara, Y. Yamada and K. Kondo, Agric. Biol. Chem., 39, 2261 (1975).

6) Y. Tahara, Y. Yamada and K. Kondo, Agric. Biol. Chem., 40, 2355 (1976).

7) E. G. Bligh and W. J. Dyer, Can. J. Biochem. Physiol., 37, 911 (1959).

8) H. J. Forster, K. Biemann, W. G. Haigh, N. H. Tattrie and J. R. Colvin, Biochem. J., 135, 133 (1973).

9) M. Rohmer and G. Ourisson, Tetrahedron Lett., 1976, 3641.

10) W. Stoffel, Ann. Rev. Biochem:, 40, 57 (1971).

11) V. Rizza, A. N. Tucker and D. C. White, $J$. Bacteriol., 101, 84 (1970).

12) E. Miyagawa, R. Azuma, T. Suto and I. Yano, $J$. Biochem., 86, 311 (1979).

13) J. E. Kunsman, J. Bacteriol., 113, 1121 (1973).

14) W. Stoffel, K. Dittmer and R. Wilmes, HoppeSeyler's Z. Physiol. Chem., 356, 715 (1975).

15) S. Steiner, S. F. Conti and R. L. Lester, J. Bacteriol., 116, 1199 (1973).

16) I. Yano, A. Yamamoto, Y. Ohno, M. Masui and E. Yabuuchi, Shishitsu Seikagaku Kenkyu, 19, 19 (1977).

17) A. Yamamoto, I. Yano, M. Masui and E. Yabuuchi, J. Biochem., 83, 1213 (1978) 